\title{
Spatiotemporal patterns of phenology of the alien Phaeophyceae Sargassum muticum on the Atlantic coast of Morocco
}

\author{
Samir El Atouani ${ }^{1}$, Zahira Belattmania ${ }^{1}$, Soukaina Kaidi ${ }^{1}$, Aschwin H. Engelen ${ }^{2}$, \\ Ester A. Serrão ${ }^{2}$, Abdellatif Chaouti ${ }^{1}$, Abdeltif Reani ${ }^{1}$, Brahim Sabour ${ }^{1}$ \\ ${ }^{1}$ Research Unit Phycology, Blue Biodiversity and Biotechnology, P3B-LB2VE, Department of Biology, \\ Faculty of Sciences, Chouaib Doukkali University, El Jadida, Morocco. \\ (SE) E-mail: elatouanisamir@gmail.com. ORCID-iD: https://orcid.org/0000-0001-5885-7419 \\ (ZB) (Corresponding author) E-mail: Belattmania.z@ucd.ac.ma. ORCID-iD: https://orcid.org/0000-0003-1415-3625 \\ (SK) E-mail: souk.kaidi@gmail.com. ORCID-iD: https://orcid.org/0000-0003-3016-8691 \\ (AC) E-mail: chaouti@ucd.ac.ma. ORCID-iD: https://orcid.org/0000-0003-2840-7059 \\ (AR) E-mail: abreani@yahoo.fr. ORCID-iD: https://orcid.org/0000-0002-9380-3595 \\ (BS) E-mail: Sabour.b@ucd.ac.ma. ORCID-iD: https://orcid.org//0000-0002-5569-0980 \\ ${ }^{2}$ CCMAR - Centre of Marine Sciences, University of Algarve, Faro, Portugal. \\ (AHE) E-mail: aengelen@ualg.pt. ORCID-iD: https://orcid.org/0000-0002-9579-9606 \\ (EAS) E-mail: eserrao@ ualg.pt. ORCID-iD: https://orcid.org/0000-0003-1316-658X
}

\begin{abstract}
Summary: The present study focused on the dynamics of the phenology and life cycle of the Phaeophyceae invader Sargassum muticum at three sites on the Atlantic coast of Morocco over a period of two years (2013 and 2014). The results showed that $S$. muticum has two distinct growth phases; one with slower growth in winter followed by one with faster growth in spring-early summer, when the species exhibited high elongation and branching activities with thalli length ranging from 1 to more than $5 \mathrm{~m}$ depending on the study site. The site S1, with a rocky substratum covered by submerged sands, promotes thalli elongation, with maximum lengths of $643.33 \pm 11.10 \mathrm{~cm}$ recorded in July. At the rocky sites (S2 and S3), the maximum length of the seaweed depends on the pools' depth. Although the elongation of thalli is enhanced by the water body depth, the settlements' density $\left(5-48\right.$ ind. $\left.\mathrm{m}^{-2}\right)$ seems to be mainly related to the nature of the substrate. The maturity index progressively increases from spring to early summer, when it reaches the highest values. S. muticum seems to be more abundant and more easily acclimated in shallow rockpools (sufficiently lighted and semi-exposed to wave action at the mid and lower tidal levels) than in protected sandy bottom sites with low hydrodynamic forces.
\end{abstract}

Keywords: population dynamics; Invasive macroalga; Sargassum muticum; Moroccan coastline.

Patrones espacio-temporales de la fenología de la feoficea exótica Sargassum muticum en la costa atlántica de Marruecos

Resumen: El presente trabajo se centró en el estudio de la fenología y el ciclo de vida del alga parda invasora Sargassum muticum en tres localidades de la costa atlántica de Marruecos durante dos años (2013 y 2014). Los resultados mostraron que $S$. muticum tiene dos fases de crecimiento distintas; la primera se caracteriza por un crecimiento más lento y ocurre durante el invierno, y la segunda fase caracterizada por un crecimiento más rápido ocurre durante la primavera y principios del verano, cuando la especie mostró una alta tasa de elongación y ramificación alcanzando longitudes entre 1 y más de 5 $\mathrm{m}$ dependiendo del sitio de estudio. El sitio S1, donde el sustrato rocoso estuvo cubierto por arena, los talos presentaron una mayor elongación con longitudes máximas de $643.33 \pm 11.10 \mathrm{~cm}$ registradas en julio. En los sitios rocosos (S2 y S3), la longitud máxima de las algas dependió de la profundidad de las piscinas. Aunque el alargamiento de los talos fue mayor con la profundidad, la densidad de los asentamientos (5-48 ind. $\mathrm{m}^{-2}$ ) parece estar principalmente relacionada con la naturaleza del sustrato. El índice de madurez aumentó progresivamente desde la primavera hasta principios del verano alcanzando los valores más altos durante el verano. S. muticum parece ser más abundante y se aclimata mejor en pozas rocosas poco profundas (suficientemente iluminadas y semi-expuestas a la acción del oleaje en los niveles medios e inferiores del intermareal), que en sitios protegidos de fondos arenosos con bajas fuerzas hidrodinámicas.

Palabras clave: dinámica de poblaciones; macroalga invasora; Sargassum muticum; costa marroquí.

Citation/Como citar este artículo: El Atouani S., Belattmania Z., Kaidi S., Engelen A.H., Serrão E.A., Chaouti A., Reani A., Sabour B. 2021. Spatiotemporal patterns of phenology of the alien Phaeophyceae Sargassum muticum on the Atlantic coast of Morocco. Sci. Mar. 85(2): 103-111. https://doi.org/10.3989/scimar.05118.010

Editor: E. Cebrián.

Received: August 28, 2020. Accepted: February 22, 2021. Published: May 28, 2021.

Copyright: $\odot 2021$ CSIC. This is an open-access article distributed under the terms of the Creative Commons Attribution 4.0 International (CC BY 4.0) License. 


\section{INTRODUCTION}

Sargassum muticum (Yendo) Fensholt (Yendo 1907) is regarded as one of the most aggressive introduced marine macroalgae (Boudouresque and Verlaque 2002). It is widely distributed in the Pacific Northwest from Kuri and Sakhalin Island in Russia to Haifong in southern China (Yamada 1956, Kang 1966, Yoshida 1983). S. muticum was observed outside its original range for the first time on the North American Pacific coast of British Columbia, Canada (Scagel 1956). Subsequently, it reached northern California (USA) (Abbott and Hollenberg 1976) and Mexico (Devinny 1978). The spread of this species continued towards the south along the west coast of Baja California (Espinoza 1990). In Europe, populations of $S$. muticum have been recorded in France (Critchley et al. 1983, Gruet 1983), the Netherlands (Prud'Homme and Nienhuis 1982) and the United Kingdom (Jones and Farnham 1973). S. muticum has also been reported in the Mediterranean (Critchley et al. 1983, Knoepffler-Péguy et al. 1985, Curiel et al. 1995). S. muticum is now present on most of the European Atlantic coasts and continues to spread in particular on the southern coasts of the Iberian Peninsula (Bermejo et al. 2012) and in the British Isles (Engelen et al. 2015). It has also reached the north Atlantic coast of Africa (Sabour et al. 2013).

The temporal and spatial variation of growth, density and reproduction of $S$. muticum populations in different regions have been described previously (e.g. Pedersen et al. 2005, Plouguerné et al. 2006, Baer and Stengel 2010). Generally, S. muticum length varies from $75 \mathrm{~cm}$ (DeWreede 1978, Gorham and Lewey 1984, Espinoza 1990) to $150 \mathrm{~cm}$ (Critchley et al. 1987, Givernaud et al. 1991, Wernberg et al. 2001), but the length can exceed $2 \mathrm{~m}$ (e.g. 5 m: Gorham and Lewey 1984, 2.5-10 m: Karlsson and Loo 1999, Sabour et al. 2013, Belattmania et al. 2018).

Several factors have been highlighted as potential determinants of ecological success, including, includ- ing air and water temperature, substrate type, hydrodynamic conditions and habitat typology. Previous studies have reported local variability in $S$. muticum densities depending on exposure (Viejo 1997), grazing pressure (Plouguerné et al. 2006) and seabed topography (Harries et al. 2007a, b). Growth and reproduction in S. muticum are supported by relatively warm water (up to $25^{\circ} \mathrm{C}$ ) (Hales and Fletcher 1990), but high air temperatures and long spawning periods in rocky habitats have a negative impact on gamete release (Engelen et al. 2008). It has been reported that the development and morphological variation between $S$. muticum populations in different Irish coastal habitats is related to the degree of exposure to the waves (Baer and Stengel 2010). Given the quasi-synchronous colonization of these different habitats, these authors suggested that phenotypic plasticity was the most likely explanation for such variations.

The present work aims to investigate the spatiotemporal dynamics of the newly established populations of $S$. muticum in different habitats with different topographic profiles on the Atlantic coast of Morocco. This study is the first of its kind carried out on African coasts outside the boreal biogeographic regions and at the southernmost latitudes of the Mauritanian region. Furthermore, it will help fill the knowledge gap in data necessary for any trial of rational valorization, control or eradication.

\section{MATERIALS AND METHODS}

\section{Sampling sites}

Three sampling sites located along the El Jadida shoreline (northwestern Atlantic coast of Morocco) with different topographic profiles favourable to the development of well settled stands of this alga were chosen (Fig. 1). Site S1, located at the southern lim-

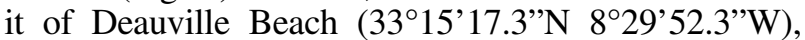
consists of a sandy beach with shallow intertidal soft

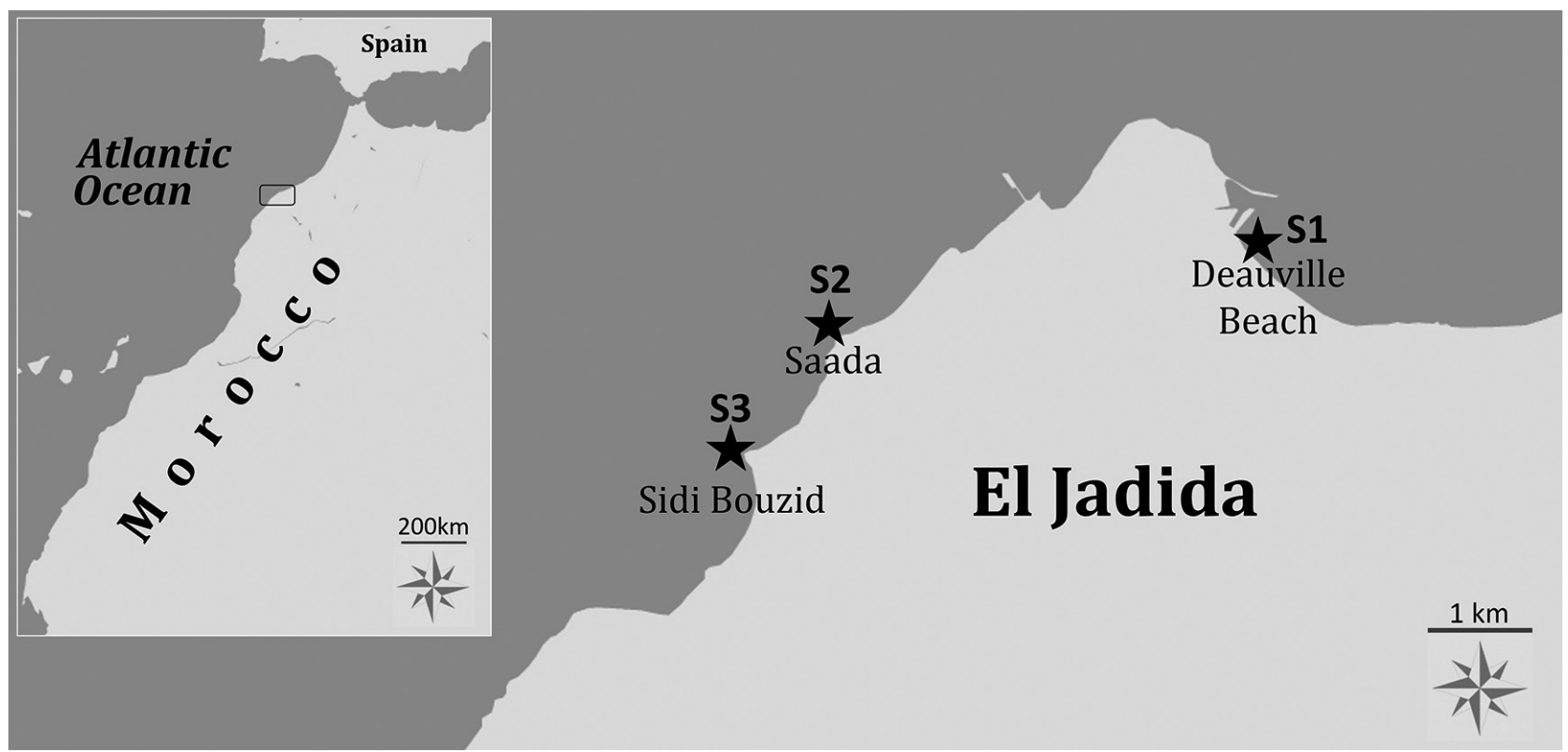

Fig. 1. - Geographical location of the study sites. 
Table 1. - Three-way ANOVA testing the effect of site (3 levels), month (12 levels) and year ( 2 levels) as fixed factors on the thalli length, density and maturity index of Sargassum muticum communities on the Moroccan Atlantic coasts. Df, degree of freedom; the global F-ratios and p-values are shown.

\begin{tabular}{|c|c|c|c|}
\hline Source of variation & Df & $\mathrm{F}$ & $\mathrm{p}$ \\
\hline \multicolumn{4}{|l|}{ Length } \\
\hline Site & 2 & 488.964 & 0.001 \\
\hline Month & 11 & 3765.397 & 0.001 \\
\hline Year & 1 & 517.849 & 0.001 \\
\hline Site $\times$ month & 22 & 378.826 & 0.001 \\
\hline Site $\times$ year & 2 & 241.165 & 0.001 \\
\hline Month $\times$ year & 11 & 44.221 & 0.001 \\
\hline Site $\times$ month $\times$ year & 22 & 118.433 & 0.001 \\
\hline Residual & 1830 & & \\
\hline \multicolumn{4}{|l|}{ Density } \\
\hline Site & 2 & 240.122 & 0.001 \\
\hline Month & 11 & 49.880 & 0.001 \\
\hline Year & 1 & 35.039 & 0.001 \\
\hline Site $\times$ month & 22 & 14.011 & 0.001 \\
\hline Site $\times$ year & 2 & 0.952 & 0.387 \\
\hline Month $\times$ year & 11 & 8.842 & 0.001 \\
\hline Site $\times$ month $\times$ year & 22 & 1.965 & 0.006 \\
\hline Residual & 504 & & \\
\hline \multicolumn{4}{|l|}{ Maturity index } \\
\hline Site & 2 & 118.562 & 0.001 \\
\hline Month & 11 & 1379.313 & 0.001 \\
\hline Year & 1 & 1.587 & 0.208 \\
\hline Site $\times$ month & 22 & 23.453 & 0.001 \\
\hline Site $\times$ year & 2 & 13.558 & 0.001 \\
\hline Month $\times$ year & 11 & 12.156 & 0.001 \\
\hline Site $\times$ month $\times$ year & 22 & 11.777 & 0.001 \\
\hline Residual & 528 & & \\
\hline
\end{tabular}

bottoms and a few patches of hard substrates. The thalli of $S$. muticum are fixed on intertidal bedrock covered with sand. The alga forms a scattered stand with large submerged thalli that exceptionally reach $7 \mathrm{~m}$. Site S2 $\left(33^{\circ} 14^{\prime} 44.7^{\prime \prime} \mathrm{N} 8^{\circ} 32^{\prime} 33.0^{\prime \prime} \mathrm{W}\right)$ consists of a large intertidal platform ( $>200 \mathrm{~m}$ ) of rocky substratum (bedrocks) with a noteworthy roughness and sheltered shallow tidal rockpools oriented northwestwards. These rockpools shelter a dense and extensive canopy of $S$. muticum populations protected against the strong wave action by artificial walls called bechkiras. Site S3 (3313'55.8’N $\left.8^{\circ} 33^{\prime} 24.8^{\prime \prime} \mathrm{W}\right)$, located to the south of El Jadida, corresponds to a large subhorizontal rocky platform. At this site, S. muticum populations are limited to rocky intertidal pools with water mass depths varying from 0.5 to $1 \mathrm{~m}$.

\section{Field surveys and sampling design}

At the three study sites, monthly samplings were carried out at low tides using $1 \mathrm{~m}^{2}$ quadrats $(1 \times 1 \mathrm{~m})$ random-

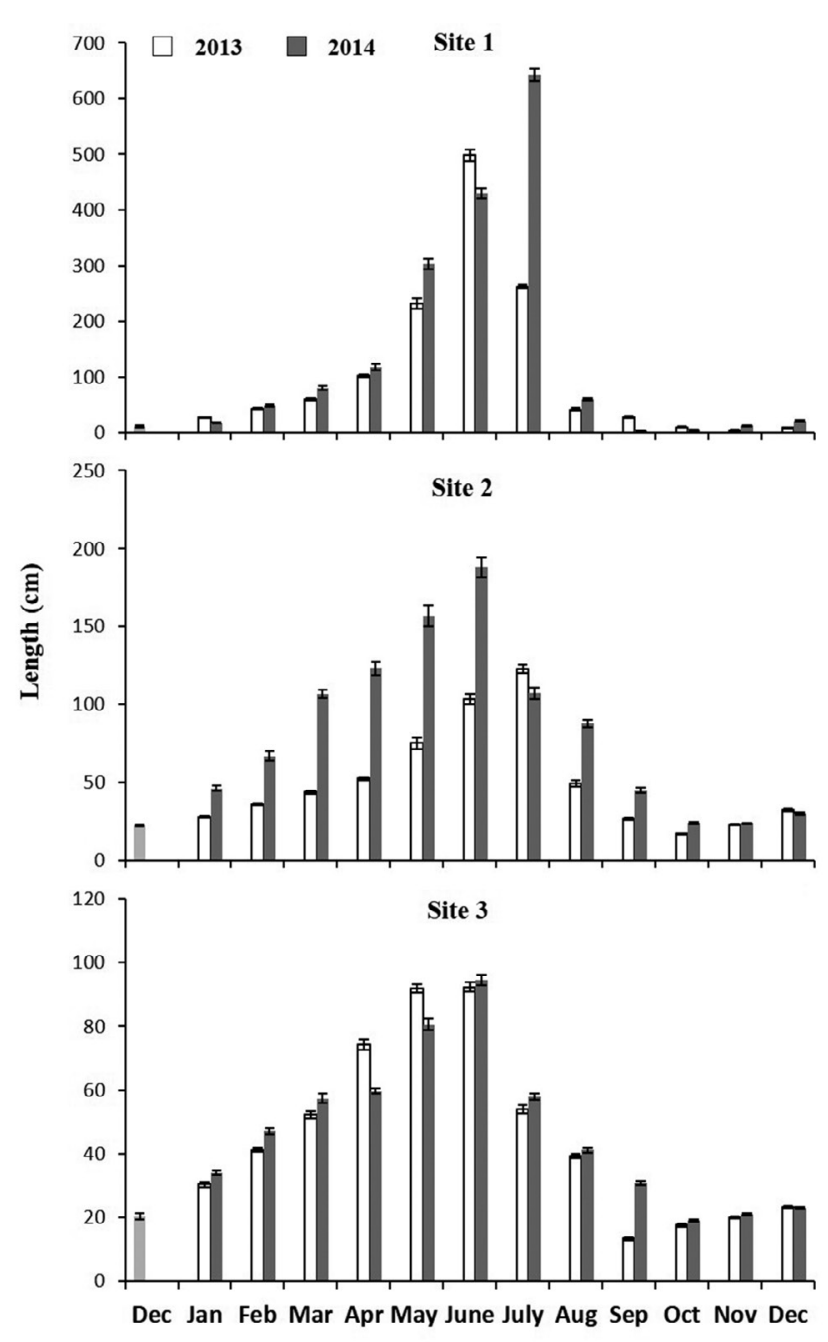

Fig. 2. - Variation of Sargassum muticum thalli length over time (2013 and 2014) in the habitats (site 1, sandy beach; sites 2 and 3 , rocky platforms) of the Atlantic coast of Morocco. $n=15$, error bars represent standard error.

ly positioned on a linear transect parallel to the shore and spaced $10 \mathrm{~m}$ from the middle intertidal zone. Density, length and maturity index of $S$. muticum were measured monthly from December 2012 to December 2014.

Density was considered as the total number of thalli (individuals) per sampled area $\left(1 \mathrm{~m}^{2}\right)$. The length of thallus was measured from the fixation discs to the apical part of the longest primary lateral (Plouguerné et al. 2006). The maturity of $S$. muticum was regarded as the appearance of the receptacles on the tertiary branches. The maturity index indicates the ratio of the number of mature individuals to the total number of individuals.

\section{Statistical analyses}

Three-way ANOVA was applied to test for the effects of sampling site and time (month and year) on density, maturity index and length of thalli, considering site, month and year as fixed factors. When significant effects of these factors were found, the post hoc com- 

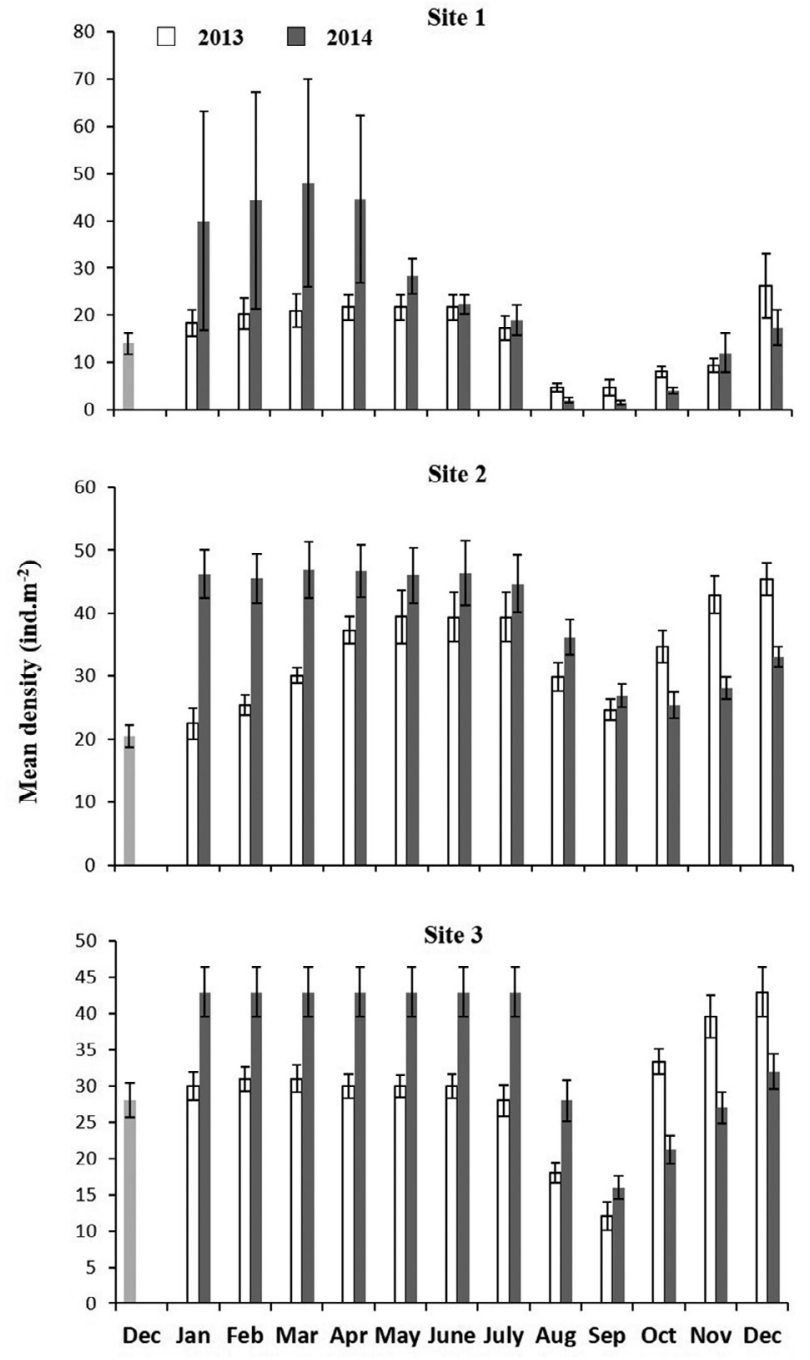

Fig. 3. - Temporal variation of the density of Sargassum muticum stands in the habitats (site 1, sandy beach; sites 2 and 3, rocky platforms) of the Atlantic coast of Morocco. $n=3$, error bars represent standard error.

parisons were based on Tukey's pairwise comparison test. Prior to ANOVA tests, the homogeneity of variances and normality were verified using the Kolmogorov-Smirnov test and the Levene test, respectively. When these parametric tests were not met, data were $\log (\mathrm{x}+1)$-transformed to remove heteroscedasticity (Underwood 1997). These statistical analyses were carried out in SPSS v 23.

\section{RESULTS}

The monitoring of S. muticum phenology showed that the thalli length varies significantly between sites and months, and between years (Table 1), except for May and July (Tukey post hoc comparison; $p>0.05$ ) and September and December (Tukey post hoc comparison; $p>0.05$ ). The longest thalli were detected at the Deauville Beach site (Fig. 2), with maximum lengths of $498.14 \pm 11.10$ and $643.33 \pm 11.10 \mathrm{~cm}$ in June 2013 and July 2014, respectively. At site S2, the lengths of thalli
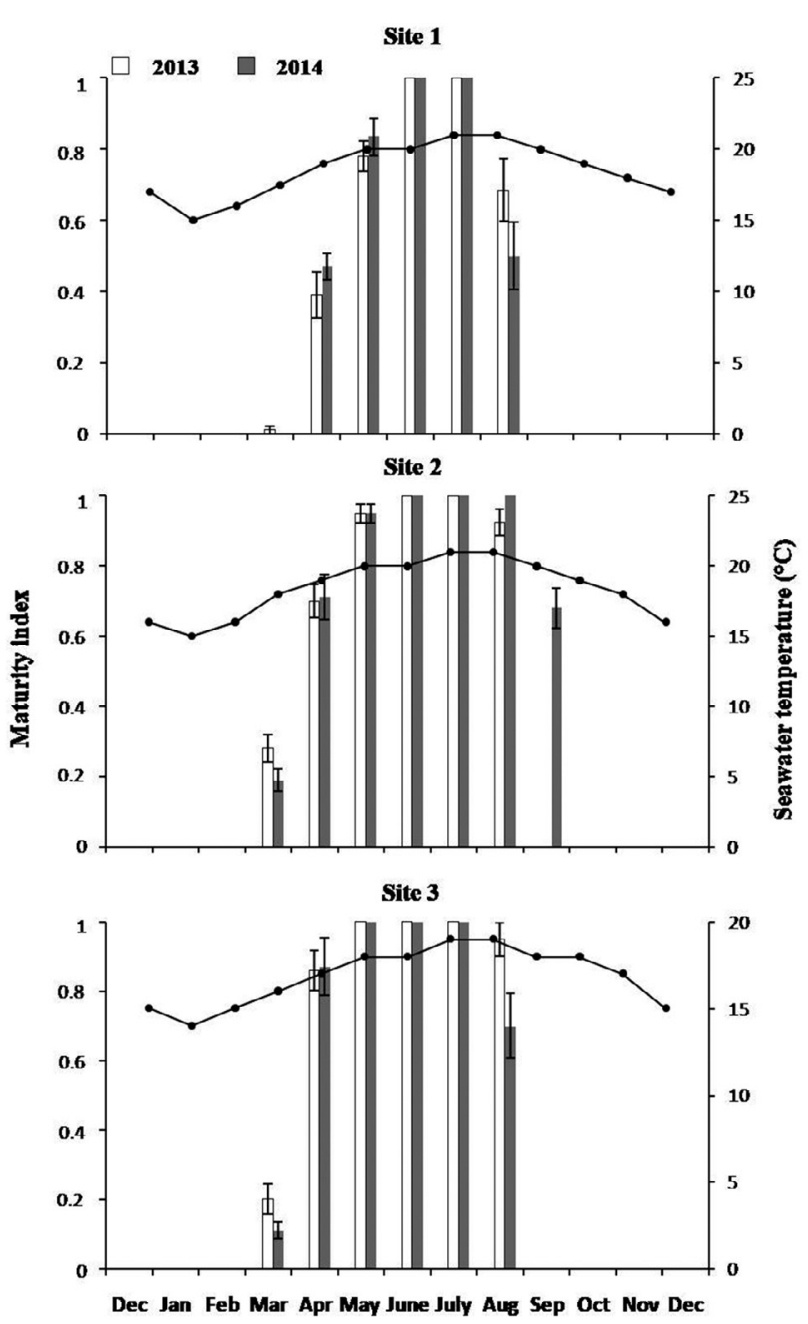

Fig. 4. - Temporal variability of the maturity index of Sargassum muticum populations (bars, primary axis) and seawater temperature (line, secondary axis) at each study site. $n=10$, error bars represent standard error.

reached the highest values of $188 \pm 3.73 \mathrm{~cm}$ in June 2014 (Fig. 2). However, the greatest alga length did not exceed $95 \pm 1.65 \mathrm{~cm}$ at site S3 (Fig. 2). The alga grows gradually from autumn, when primary branches rise from the perennial part, bearing large basal leaves whose role is probably to increase the photosynthetic surface. As primary lateral growth progresses, air vesicles and secondary branches begin to develop. The air vesicles keep the seaweed straight in the water column towards the surface. In early summer (June-July), the thalli elongation slows down before reaching maximum values $(6 \mathrm{~m})$. At the end of the summer (mid-August to September), thalli length plummets because the vegetative growth rate declines rapidly and lateral branches start to degenerate leaving only a discoid holdfast from which primary laterals regenerate during the following winter.

The density of $S$. muticum stands depicted significant spatiotemporal variations over two years, 2013 and 2014 (ANOVA, $\mathrm{p}<0.01$ ), with no significant interaction effect of the factors site and year (Table 1). At 
Table 2. - Tukey post hoc comparison testing the effects of site and sampling month on the thalli length, density and maturity index of Sargassum muticum communities on the Moroccan Atlantic coasts. Significant p-values are shown in bold.

\begin{tabular}{|c|c|c|c|}
\hline & Length & Density & Maturity index \\
\hline \multicolumn{4}{|l|}{ Site } \\
\hline $\mathrm{S} 1 / \mathrm{S} 2$ & 0.000 & 0.000 & 0.000 \\
\hline $\mathrm{S} 1 / \mathrm{S} 3$ & 0.000 & 0.000 & 0.000 \\
\hline $\mathrm{S} 2 / \mathrm{S} 3$ & 0.000 & 0.006 & 0.001 \\
\hline \multicolumn{4}{|l|}{ Month } \\
\hline Jan / Feb & 0.000 & 0.989 & 1.000 \\
\hline Jan / Mar & 0.000 & 0.355 & 0.000 \\
\hline Jan / Apr & 0.000 & 0.019 & 0.000 \\
\hline Jan / May & 0.000 & 0.070 & 0.000 \\
\hline Jan / June & 0.000 & 0.152 & 0.000 \\
\hline Jan / July & 0.000 & 0.555 & 0.000 \\
\hline Jan / Aug & 0.000 & 0.000 & 0.000 \\
\hline Jan / Sep & 0.000 & 0.000 & 0.000 \\
\hline Jan / Oct & 0.000 & 0.001 & 1.000 \\
\hline Jan / Nov & 0.000 & 1.000 & 1.000 \\
\hline Jan / Dec & 0.000 & 1.000 & 1.000 \\
\hline Feb / Mar & 0.000 & 0.981 & 0.000 \\
\hline Feb / Apr & 0.000 & 0.423 & 0.000 \\
\hline Feb / May & 0.000 & 0.715 & 0.000 \\
\hline Feb / June & 0.000 & 0.877 & 0.000 \\
\hline Feb / July & 0.000 & 0.998 & 0.000 \\
\hline Feb / Aug & 0.000 & 0.000 & 0.000 \\
\hline Feb / Sep & 0.000 & 0.000 & 0.000 \\
\hline Feb / Oct & 0.000 & 0.000 & 1.000 \\
\hline Feb / Nov & 0.000 & 0.705 & 1.000 \\
\hline Feb / Dec & 0.000 & 0.687 & 1.000 \\
\hline Mar / Apr & 0.000 & 0.995 & 0.000 \\
\hline Mar/ May & 0.000 & 1.000 & 0.000 \\
\hline Mar / June & 0.000 & 1.000 & 0.000 \\
\hline Mar / July & 0.000 & 1.000 & 0.000 \\
\hline Mar / Aug & 0.000 & 0.000 & 0.000 \\
\hline Mar / Sep & 0.000 & 0.000 & 0.999 \\
\hline Mar / Oct & 0.000 & 0.000 & 0.000 \\
\hline Mar / Nov & 0.000 & 0.053 & 0.000 \\
\hline Mar / Dec & 0.000 & 0.049 & 0.000 \\
\hline Apr/ May & 0.000 & 1.000 & 0.000 \\
\hline
\end{tabular}

\begin{tabular}{|c|c|c|c|}
\hline & Length & Density & Maturity index \\
\hline Apr / June & 0.000 & 1.000 & 0.000 \\
\hline Apr / July & 0.000 & 0.966 & 0.000 \\
\hline Apr / Aug & 0.000 & 0.000 & 0.000 \\
\hline Apr / Sep & 0.000 & 0.000 & 0.000 \\
\hline Apr / Oct & 0.000 & 0.000 & 0.000 \\
\hline Apr / Nov & 0.000 & 0.001 & 0.000 \\
\hline Apr / Dec & 0.000 & 0.001 & 0.000 \\
\hline May / June & 0.000 & 1.000 & 0.000 \\
\hline May / July & 0.171 & 0.998 & 0.000 \\
\hline May / Aug & 0.000 & 0.000 & 0.000 \\
\hline May / Sep & 0.000 & 0.000 & 0.000 \\
\hline May / Oct & 0.000 & 0.000 & 0.000 \\
\hline May / Nov & 0.000 & 0.005 & 0.000 \\
\hline May / Dec & 0.000 & 0.005 & 0.000 \\
\hline June / July & 0.000 & 1.000 & 1.000 \\
\hline June / Aug & 0.000 & 0.000 & 0.000 \\
\hline June / Sep & 0.000 & 0.000 & 0.000 \\
\hline June / Oct & 0.000 & 0.000 & 0.000 \\
\hline June / Nov & 0.000 & 0.015 & 0.000 \\
\hline June / Dec & 0.000 & 0.013 & 0.000 \\
\hline July / Aug & 0.000 & 0.000 & 0.000 \\
\hline July / Sep & 0.000 & 0.000 & 0.000 \\
\hline July / Oct & 0.000 & 0.000 & 0.000 \\
\hline July / Nov & 0.000 & 0.119 & 0.000 \\
\hline July / Dec & 0.000 & 0.111 & 0.000 \\
\hline Aug / Sep & 0.000 & 0.001 & 0.000 \\
\hline Aug / Oct & 0.000 & 1.000 & 0.000 \\
\hline Aug / Nov & 0.000 & 0.010 & 0.000 \\
\hline Aug / Dec & 0.000 & 0.011 & 0.000 \\
\hline Sep / Oct & 0.000 & 0.000 & 0.000 \\
\hline Sep / Nov & 0.000 & 0.000 & 0.000 \\
\hline Sep / Dec & 1.000 & 0.000 & 0.000 \\
\hline Oct / Nov & 0.000 & 0.026 & 1.000 \\
\hline Oct / Dec & 0.000 & 0.028 & 1.000 \\
\hline Nov / Dec & 0.000 & 1.000 & 1.000 \\
\hline
\end{tabular}

site S1, despite the heterogeneous spatial distribution of the alga, the density recorded in the winter and early spring of 2014 showed high average values ranging from 40 to 48 ind. $\mathrm{m}^{-2}$ before falling sharply (28 ind. $\mathrm{m}^{-2}$ ) in May 2014 (Fig. 3). In contrast to Deauville Beach (S1), at S2 and S3 the S. muticum stands in the rocky pools (Fig. 3) maintained high average densities from winter to early summer (23-39 ind. $\mathrm{m}^{-2}$ in 2013, 43-46 ind. $\mathrm{m}^{-2}$ in 2014), with significant differences

between August and September and the cold months; Table 2), when the species naturally degenerates after the reproductive period.

Spatiotemporal monitoring of $S$. muticum maturity showed that the maturity index varied significantly between sites and months (except for October, November, December, January and February, Tukey post hoc comparison; Table 2), with no significant differences between years $(\mathrm{p}>0.05$; Table 1$)$. The thalli at $\mathrm{S} 1$ began to 
develop receptacles on the tertiary branches from April (maturity index $=0.39$ ). However, at S2 and S3, the appearance of these reproductive organs was earlier, from March 2013 and 2014, during which the maturity rates varied from 0.11 to 0.28 depending on the site (Fig. 4). Apart from the delay in the appearance of receptacles at $\mathrm{S} 1$, the maturity gradually increased from early spring to reach a maximum value of 1 (corresponding to a maturity rate of $100 \%$ ) in early summer, with water temperatures reaching $20^{\circ} \mathrm{C}$ (Fig. 4).

\section{DISCUSSION}

The seasonal variation in the length of $S$. muticum thalli on the Moroccan Atlantic coasts corresponds to the classical pattern often observed in the life cycle of $S$. muticum, with three characterizing stages: slow initial growth; fast growth and lateral elongation; and reproduction and degeneration (Wernberg-Møller et al. 1998). Some authors subdivide the growth rhythm of this species into two phases: one of moderate growth in autumn-winter with a slow increase in thallus length, and one of strong growth during the spring-summer period (Arenas et al. 1995).

On a global geographic scale, $S$. muticum has shown a latitudinal variation in the phenology of vegetative growth and plasticity in the niche of the reproductive period. In the paralysis zone of Limfjorden in Denmark, the species depicted rapid growth from May to July followed by a phase of senescence when maturity reached its maximum (Wernberg-Møller et al. 1998). The same growth pattern has been demonstrated in Canada (DeWreede 1978), the United Kingdom (Jephson and Gray 1977, Gorham and Lewey 1984), the Netherlands (Critchley et al. 1987), France (Givernaud et al. 1991) and Spain (Arenas et al. 1995), although there are some latitudinal differences in the timing of the growth cycle, probably due to environmental stimuli (Norton and Deysher 1989, Hales and Fletcher 1990, Arenas et al. 1995). In the south of England, no dormancy period has been recorded since the growth of a generation begins before the lateral branches of the previous year are completely decomposed (Jephson and Gray 1977). Hwang and Dring (2002) highlighted the role of the photoperiod on the elongation of the seedlings of S. muticum. They demonstrated a back-up of growth starting under short photoperiods (8.16) corresponding to winter conditions. Furthermore, Uchida et al. (1991) reported that the lengthening of branches is promoted by short day conditions. In southern Europe, the winter dormancy period is not always obvious, however. Vegetative growth is high from winter to early summer, resulting in maximum lengths exceeding 4 metres (Sfriso and Facca 2013). On the Atlantic coasts of Morocco, $S$. muticum does not seem to exhibit clear winter dormancy but nevertheless shows a marked seasonality in terms of growth and reproduction, with maxima during the spring-summer period.

The spatial variation in thalli length detected in the present study seems to be linked to the prevailing typology and hydrodynamism caracterizing each sampling site: at site $\mathrm{S} 1$, rocky bed covered by sand, is an open environment with fairly significant depths continuously immersed and semi-protected by the harbour jetty, promotes the elongation of the thalli, which undergo their highest vegetative growth from winter to early summer. However, shallow rockpools at both S2 and S3 limit the length and the apical growth of $S$. muticum thalli, which are frequently truncated at the ends of their primary axes on the surface of the pool under wave action. This promotes lateral branching. The same finding was previously reported by Chamberlain et al. (1979). According to Lann et al. (2012), S. muticum thalli at sheltered, sandy-bed sites are three times longer than those at exposed, bedrock sites. This variation in the thalli length of S. muticum as a function of the biotope has also been demonstrated in other studies (Andrew and Viejo 1998a, b, Engelen et al. 2005, Plouguerné et al. 2006). It has been reported that the length of $S$. muticum on the Normandy coasts (France) depends mainly on the depth of water available in the pools and the bathymetric level (Givernaud et al. 1991). In its native region of southeastern Asia, S. muticum is considered to be a scarce species among the local macroalgal flora, reaching a maximum of 1 to 2 metres in length. However, outside its native range, the species is invasive and can forms dense stands with thalli length up to 16 meters (Critchley et al. 1983).

If the thalli length is rather favoured by the depth of the water mass, the density of S. muticum stands seems to be mainly a function of the substrate nature (at sites $\mathrm{S} 2$ and $\mathrm{S} 3$, with rocky substrata, the alga provided the highest densities), a finding corroborating the conclusions of Givernaud et al. (1991) on the coasts of Basse-Normandie in France. Additionally, Harries et al. (2007a, b) reported that the density of the species decreases as depth increases and, thus, light decreases. As for most algal species inhabiting the horizons of the intertidal zone, the density of S. muticum varies according to the bathymetric level, rarely emerging as it is not very resistant to desiccation and abundant, especially in pools of middle and lower levels (Givernaud et al. 1991, Engelen et al. 2015). At site $S 1$, where the thalli are immersed in a column of water continuously exceeding $1 \mathrm{~m}$, the low luminosities could be added to the substrate nature to explain the early decrease in the density of the species from early spring. At sites S2 and S3, S. muticum is abundant, particularly in shallow rockpools that are sufficiently lit in the middle and low tidal zones. The species almost disappears from the high tidal and lowest low-tide zones. In addition to the substrate nature and the bathymetry, some authors (e.g. Stæhr et al. 2000, Plouguerné et al. 2006, Thomsen et al. 2006) have raised the role of hydrodynamics in the settlement of this species. Le Lann (2009) demonstrated that the species density is higher at a rocky exposed site than at a sandy and sheltered site. Seasonal changes in water movement could be the main factor influencing the density of Sargassaceae populations (Plouguerné et al. 2006). For S. muticum, the density can vary significantly over short periods because of high 
recruitment events in the autumn and the rapid growth of individuals in spring (Thomsen et al. 2006). Generally, the density of $S$. muticum is dependent on the substrate type and hydrodynamics. This macroalgal species acclimates more easily at rocky and semi-exposed sites than at sites with a sandy, protected substrate with low water mass circulation.

The slight shift in the maturity timing of $S$. muticum at site $\mathrm{S} 1$ is probably linked to the typology and hydrodynamic conditions in comparison with those at sites S2 and S3. In these two habitats, the primary axes are continually truncated under the wave action. This promotes the branching and lateral growth of secondary and tertiary branches and, consequently, the earlier appearance of the receptacles. Similar results have been made by Gaylord et al. (1994), Viejo et al. (1995) and Le Lann (2009), who reported that the laterals of individuals living on exposed zones are often torn by waves or swells when they reach a critical length. This also agrees with the results previously discussed for the elongation of thalli at the Deauville Beach site (S1), which seems to take precedence over branching and thus results in maximum length of 5 to $6.4 \mathrm{~m}$, whereas at sites S2 and S3 S. muticum hardly exceeds maxima of 1.2 to $1.9 \mathrm{~m}$ and $0.9 \mathrm{~m}$, respectively.

The period of the reproductive cycle of $S$. muticum varies among regions according to the geographical latitude (Engelen et al. 2015). Along the west coast of North America, the reproduction season extends from June to September. However, in areas further south, the reproduction period tends to start earlier and last longer (Norton and Deysher 1989). On the northwest coast of Baja California, Mexico, fertile individuals may be present throughout the year, with a peak of maturity in spring and summer (Aguilar-Rosas and Machado-Galindo 1990). On the European coasts, the mature thalli of $S$. muticum can be observed in early spring, in summer and until early autumn. In northern Europe, the annual life cycle of $S$. muticum includes the following phases: initial growth in spring, elongation in early summer, reproduction in summer and degeneration in autumn (Wernberg-Møller et al. 1998). In Denmark, however, the number of mature individuals is high in July and August. In Ireland, receptacle development typically begins in June and the breeding period is short and is limited to August (Baer and Stengel 2010). In southern England, S. muticum reaches reproductive maturity between July and September (Jephson and Gray 1977). On the Brittany coast of France, mature individuals are observed until the autumn (Le Lann et al. 2012). In southern Europe, thalli of S. muticum develop reproductive receptacles from winter to early summer. On the north coast of Portugal, the breeding period can last from April to August, while in the south, the maturity phase of the cycle lasts from January to September depending on the location (Engelen et al. 2008). All of these studies therefore suggest a latitudinal dependence in the phenology of $S$. muticum. The maturity period is increasingly precocious and spread out as one moves from norther towards southern latitudes. These differences in reproductive phenology are generally linked to the geographic variation of environmental variables rather than to physiological differences in populations themselves at their different latitudes.

Although higher water temperatures generally lead to faster development of receptacles and early reproduction of the alga (Norton and Deysher 1989), this statement is not valid for all populations of $S$. muticum. For example, Aguilar-Rosas and Machado-Galindo (1990) reported that the peak of the reproductive period on the coasts of Baja California occurs much later than expected, though mature reproductive individuals are present throughout the year. This delay has been attributed to the upwelling effect along these coasts (Aguilar-Rosas and Machado-Galindo 1990). In addition to the water temperature, the length of days is important in the timing of $S$. muticum reproduction. Despite these significant latitudinal variations in the maturity period of $S$. $m u$ ticum, sensu stricto reproduction is not simultaneous for all thalli. On the Moroccan coast, the increase in the maturity index from early spring indeed reveals a gradual maturation of populations to reach their maximum values at the middle of summer (July-August), when receptacles on tertiary branches become mature and reveal on their surface germinating oogonia and zygotes.

In view of the data obtained through this phenological monitoring, the harvest of $S$. muticum should be carried out in May-June, a period corresponding to the maximum growth of thalli with largely completed sexual reproduction, which ensures a sustainable valorization. Otherwise, for an invasion control approach, the species should be harvested from March to April, when populations are partially mature.

In conclusion, this study, highlighted various aspects of the dynamics of Sargassum muticum populations on the Atlantic coast of Morocco. By following two annual cycles at three sites with different topographic profiles, the results showed that this species has a spatiotemporal phenotypic plasticity favourable to installation and invasion. The life cycle of $S$. muticum on the Moroccan coastline has two distinct growth phases: slower growth in winter and faster growth phase in spring-early summer. The species then exhibits great elongation and branching activity during the spring-summer period, with a maximum thallus length of 1 to more than $5 \mathrm{~m}$ depending on the type of habitat. The rocky platform site covered with continuously submerged sand (S1) favours thalli elongation, whereas at rocky sites exposed to more marked hydrodynamic forces (S2 and S3), the maximum length of the alga is determined by the water body depth in pools. If the length of fronds is favoured by the depth of the water body, the density of the stands seems to be mainly a function of the substrate nature. Generally, S. muticum is more easily acclimated in shallow rockpools that are sufficiently lit and semi-exposed to waves in the middle and low tidal zones than at sites with sandy and protected substrates with low water circulation. 


\section{REFERENCES}

Abbott I.A., Hollenberg G.J. 1976. Marine algae of California. Stanford University Press, California, $844 \mathrm{pp}$.

Aguilar-Rosas R., Machado-Galindo A. 1990. Ecological aspects of Sargassum muticum (Fucales, Phaeophyta) in Baja California, Mexico: reproductive phenology and epiphytes. Hydrobiologia 204: 185-190. https://doi.org/10.1007/BF00040232

Andrew N., Viejo R. 1998a. Effects of wave exposure and intraspecific density on the growth and survivorship of Sargassum muticum (Sargassaceae: Phaeophyta). Eur. J. Phycol. 33: 251-258. https://doi.org/10.1080/09670269810001736753

Andrew N.L., Viejo R. 1998b. Ecological limits to the invasion of Sargassum muticum in northern Spain. Aquat. Bota. 60: 251-263.

https://doi.org/10.1016/S0304-3770(97)00088-0

Arenas F., Fernández C., Rico J.M., et al.1995. Growth and reproductive strategies of Sargassum muticum (Yendo) Fensholt and Cystoseira nodicaulis (Whit.) Roberts. Sci. Mar. 59: $1-8$.

Baer J., Stengel D.B. 2010. Variability in growth, development and reproduction of the non-native seaweed Sargassum muticum (Phaeophyceae) on the Irish west coast. Estuar. Coast. Shelf. Sci. 90: 185-194. https://doi.org/10.1016/j.ecss.2010.08.011

Belattmania Z., Chaouti A., Reani A., et al. 2018. The introduction of Sargassum muticum modifies epifaunal patterns in a Moroccan seagrass meadow. Mar. Ecol. 39: e12507. https://doi.org/10.1111/maec.12507

Bermejo R., Pérez-Llorens J.L., Vergara J.J., et al. 2012. Fragmentos taxonómicos, corológicos, nomenclaturales y fitocenológicos. Acta Bot. Malacit. 37: 163-218.

Boudouresque C.F., Verlaque M. 2002. Biological pollution in the Mediterranean Sea: invasive versus introduced macrophytes. Mar. Pollut. Bull. 44: 32-38. https://doi.org/10.1016/S0025-326X(01)00150-3

Chamberlain A.H.L., Gorham J., Kane DF., et al. 1979. Laboratory growth studies on Sargassum muticum (Yendo) Fensholt III. Apical dominance. Bot. Mar. 22: 11-19. https://doi.org/10.1515/botm.1979.22.1.11

Critchley A.T., Farnham W.F., Morrell S.L. 1983. A chronology of new European sites of attachment for the invasive brown alga, Sargassum muticum, 1973-1981. J. Mar. Biol. Assoc. U.K. 63: 799-811. https://doi.org/10.1017/S0025315400071228

Critchley A.T., Nienhuis P.H., Verschuure K. 1987. Presence and development of populations of the introduced brown alga Sargassum muticum in the southwest Netherlands. Hydrobiologia 151: 245-255. https://doi.org/10.1007/BF00046137

Curiel D., Rismondo A., Marzocchi M., et al. 1995. Distribuzione di Sargassum muticum (Yendo) Fensholt (Phaeophyta) in Laguna di Venezia. Acqua Aria 8: 831-834.

Devinny J.S. 1978. Ordination of seaweed communities: environmental gradients at Punta Banda, Mexico. Bot. Mar. 21: 357-363. https://doi.org/10.1515/botm.1978.21.6.357

DeWreede R.E. 1978. Phenology of Sargassum muticum (Phaeophyta) in the Strait of Georgia, British Columbia. Syesis 11: $1-9$

Engelen A.H., Åberg P., Olsen J.L., et al. 2005. Effects of wave exposure and depth on biomass, density and fertility of the fucoid seaweed Sargassum polyceratium (Phaeophyta, Sargassaceae). Eur. J. Phycol. 40: 149-158. https://doi.org/10.1080/09670260500109210

Engelen A.H., Espirito-Santo C., Simoes T., et al. 2008. Periodicity of propagule expulsion and settlement in the competing native and invasive brown seaweeds, Cystoseira humilis and Sargassum muticum (Phaeophyta). Eur. J. Phycol. 43: 275-282. https://doi.org/10.1080/09670260801979279

Engelen A.H., Serebryakova A., Ang P., et al. 2015. Circumglobal invasion by the brown seaweed Sargassum muticum. Oceanogr. Mar. Biol. 53: 81-126.

Espinoza J. 1990. The southern limit of Sargassum muticum (Yendo) Fensholt (Phaeophyta, Fucales) in the Mexican Pacific. Bot. Mar. 33: 193-196. https://doi.org/10.1515/botm.1990.33.2.193
Gaylord B., Blanchette C.A., Denny M.W. 1994. Mechanical consequences of size in wave-swept algae. Ecol. Monogr. 64: $287-313$. https://doi.org/10.2307/2937164

Givernaud T., Cosson J., Givernaud-Mouradi A. 1991. Étude des populations de Sargassum muticum (Yendo) Fensholt sur les côtes de Basse-Normandie (France). In: Elliott M., Ducrotoy J.P. (eds), Estuaries and Coasts: Spatial and temporal intercomparisons. ECSA 19 Symposium, University of Caen, pp. 129-132.

Gorham J., Lewey SA. 1984. Seasonal changes in the chemical composition of Sargassum muticum. Mar. Biol. 80: 103-107. https://doi.org/10.1007/BF00393133

Gruet Y. 1983. L'algue brune d'origine japonaise Sargassum muticum (Yendo) Fensholt envahit la côte francaise de l'Océan Atlantique après avoir colonisé celles de la Manche. Bull. Soc. sci. nat. Ouest Fr. 6: 1-8.

Hales J.M., Fletcher R.L. 1990. Studies on the recently introduced brown alga Sargassum muticum (Yendo) Fensholt. $\mathrm{V}$. Receptacle initiation and growth, and gamete release in laboratory culture. Bot. Mar. 33: 241-250. https://doi.org/10.1515/botm.1990.33.3.241

Harries D.B., Cook E., Donnan D.W., et al. 2007a. The establishment of the invasive alga Sargassum muticum on the west coast of Scotland: rapid northwards spread and identification of potential new areas for colonisation. Aquat. Invasions 2: 367-377. https://doi.org/10.3391/ai.2007.2.4.5

Harries D.B., Harrow S., Wilson J.R., et al. 2007b. The establishment of the invasive alga Sargassum muticum on the west coast of Scotland: a preliminary assessment of community effects. J. Mar. Biol. Assoc. U.K. 87: 1057-1067. https://doi.org/10.1017/S0025315407057633

Hwang E.K., Dring M.J. 2002. Quantitative photoperiodic control of erect thallus production in Sargassum muticum. Bot. Mar. 45: 471-475. https://doi.org/10.1515/BOT.2002.049

Jephson N.A., Gray P.W.G. 1977. Aspects of the ecology of Sargassum muticum (Yendo) Fensholt in the Solent region of the British Isles. I. The growth cycle and epiphytes. In: Keegan B.F., Ceidigh P.O., Boaden P.J.S. (eds). Biology of Benthic Organisms. Proc. 11th EMBS. Pergamon Press, Oxford, pp. 367-375. https://doi.org/10.1016/B978-0-08-021378-1.50041-5

Jones G., Farnham W. 1973. Japweed: new threat to British coasts. New Scientist 60: 394-395.

Kang J.W. 1966. On the geographical distribution of marine algae in Korea. Bull. Pusan Fish. Coll. 7: 1-125.

Karlsson J., Loo L.O. 1999. On the continuous expansion of the Japanese seaweed 2 Sargassum muticum 2 in Sweden. Bot. Mar. 42: 285-294. https://doi.org/10.1515/BOT.1999.032

Knoepffler-Péguy M., Belsher T., Boudouresque C.F., et al. 1985. Sargassum muticum begins to invade the Mediterranean. Aquat. Bot. 23: 291-295. https://doi.org/10.1016/0304-3770(85)90072-5

Le Lann K. 2009. Etude de la biodiversité des Sargassaceae (Fucales, Phaeophyceae) en milieux tempéré et tropical: écologie, chimiotaxonomie et source de composés bioactifs. $\mathrm{PhD}$ thesis, University of Western Brittany (France). $367 \mathrm{pp}$.

Le Lann K.L., Ferret C., VanMee E., et al. 2012. Total phenolic, size-fractionated phenolics and fucoxanthin content of tropical Sargassaceae (Fucales, Phaeophyceae) from the South Pacific Ocean: spatial and specific variability. Phycol. Res. 60: 37-50. https://doi.org/10.1111/j.1440-1835.2011.00634.x

Norton T.A., Deysher L.E. 1989. The reproductive ecology of Sargassum muticum at different latitudes. In: Ryland J.S., Tyler P.A. (eds). Reproduction, Genetics and Distributions of Marine Organisms. Proc. 23rd EMBS, pp. 147-152.

Pedersen M.F., Stæhr P.A., Wernberg T., et al. 2005. Biomass dynamics of exotic Sargassum muticum and native Halidrys siliquosa in Limfjorden, Denmark-implications of species replacements on turnover rates. Aquat. Bot. 83: 31-47. https://doi.org/10.1016/j.aquabot.2005.05.004

Plouguerné E., Le Lann K., Connan S., et al. 2006. Spatial and seasonal variation in density, reproductive status, length and phenolic content of the invasive brown macroalga Sargassum muticum (Yendo) Fensholt along the coast of Western Brittany (France). Aquat. Bot. 85: 337-344. https://doi.org/10.1016/j.aquabot.2006.06.011 
Prud'Homme W.F. Nienhuis P.H. 1982. Occurrence of the brown alga Sargassum muticum (Yendo) Fensholt in the Netherlands. Bot. Mar. 25: 37-39.

Sabour B., Reani A., El Magouri H., et al. 2013. Sargassum muticum (Yendo) Fensholt (Fucales, Phaeophyta) in Moroc$\mathrm{co}$, an invasive marine species new to the Atlantic coast of Africa. Aquat. Invasions 8: 97-102. https://doi.org/10.3391/ai.2013.8.1.11

Scagel R.F. 1956. Introduction of a Japanese alga, Sargassum muticum, into the Northeast Pacific. Fisheries Research Papers, Washington Department of Fisheries, 1: 49-59.

Sfriso A. Facca C. 2013. Annual growth and environmental relationships of the invasive species Sargassum muticum and Undaria pinnatifida in the lagoon of Venice. Estuar. Coast. Shelf. Sci. 129: 162-172. https://doi.org/10.1016/j.ecss.2013.05.031

Stæhr P.A., Pedersen M.F., Thomsen M.S., et al. 2000. Invasion of Sargassum muticum in Limfjorden (Denmark) and its possible impact on the indigenous macroalgal community. Mar. Ecol. Prog. Ser. 207: 79-88 https://doi.org/10.3354/meps207079

Thomsen M.S., Wernberg T., Staehr P.A., et al. 2006. Spatiotemporal distribution patterns of the invasive macroalga Sargassum muticum within a Danish Sargassum-bed. Helgol. Mar. Res. 60: 50-58. https://doi.org/10.1007/s10152-005-0016-1

Uchida T., Yoshikawa K., Arai A., et al. 1991. Life cycle and its control of Sargassum muticum in batch cultures. Nippon Suisan Gakk. 57: 2249-2253.

https://doi.org/10.2331/suisan.57.2249
Underwood AJ. 1997. Experiments in Ecology: Their Logical Design and Interpretation using Analysis of Variance. Cambridge University Press, 504 pp. https://doi.org/10.1017/CBO9780511806407

Viejo R.M., 1997. The effects of colonization by Sargassum muticum on tide pool macroalgal assemblages. J. Mar. Biol. Assoc. U.K. 77: 325-340. https://doi.org/10.1017/S0025315400071708

Viejo R.M., Arrontes J., Andrew N.L. 1995. An experimental evaluation of the effect of wave action on the distribution of Sargassum muticum in Northern Spain. Bot. Mar. 38: 437441. https://doi.org/10.1515/botm.1995.38.1-6.437

Wernberg- Møller T., Thomsen MS., Stæhr PA. 1998. Studies on the ecology of Sargassum muticum (Yendo) Fensholt in Limfjorden. MSc thesis, Department of Life Sciences and Chemistry, Roskilde University, 147 pp.

Wernberg T. Thomsen M.S., Stæhr P.A., et al. 2001. Comparative phenology of Sargassum muticum and Halidrys siliquosa (Phaeophyceae: Fucales) in Limfjorden, Denmark. Bot. Mar. 44: 31-39. https://doi.org/10.1515/BOT.2001.005

Yamada Y. 1956. On the distribution of Sargassum on the coast of Japan and its neighbouring regions. Internat. Seaweed Symp. 2: 218-220.

Yendo K. 1907. The Fucaceae of Japan. Journ. Coll. Sci. Imp. Univ. 21: 1-174.

Yoshida T. 1983. Japanese species of Sargassum subgenus Bactrophycus (Phaeophyta, Fucales). J. Faculty of Science, Hokkaido University, Series V. (Botany), 13: 99-246. 